\title{
Windstorm disturbance triggers multiple species invasion in an urban Mediterranean forest
}

\author{
Giuliano Bonanomi ${ }^{(1)}$, \\ Guido Incerti (2), \\ Ahmed M Abd El-Gawad (3), \\ Tushar C Sarker ${ }^{(1)}$, \\ Adriano Stinca ${ }^{(4)}$, \\ Riccardo Motti ${ }^{(1)}$, \\ Gaspare Cesarano ${ }^{(1)}$, \\ Maurizio Teobaldelli ${ }^{(1)}$, \\ Luigi Saulino ${ }^{(1)}$, \\ Francesco Cona ${ }^{(1)}$, \\ Giovanni Battista Chirico ${ }^{(1)}$, \\ Stefano Mazzoleni ${ }^{(1)}$, \\ Antonio Saracino ${ }^{(1)}$
}

\begin{abstract}
Plant invasion in forest ecosystems is a serious ecological and economic issue, deserving attention by researchers, managers and policy-makers worldwide. Many invasive plants have been reported as early successional species able to colonize disturbed areas following abrupt changes in microhabitat and resource availability. We investigated disturbance effects of a severe windstorm generated by a wet microburst (hail and rain at $160 \mathrm{~mm} \mathrm{~h}^{-1}$ ) remarkably affecting the canopy cover of an old-growth Quercus ilex urban forest in Southern Italy. This stand-replacing disturbance produced a mosaic of 103 gaps, 5.6 to $1632 \mathrm{~m}^{2}$ in size, over an area of $1.53 \mathrm{ha}$, uprooting $76 \%$ of the trees and decreasing thereby $85 \%$ of the standing above-ground dry biomass into the gaps. By intensive monitoring we compared above- and below-ground microclimate, soil moisture and mineral $\mathrm{N}$ availability in paired disturbed and control areas of the study forest. Within newly formed gaps we observed a seasonally consistent $70 \%$ higher content of nitrate nitrogen, $29 \%$ and $47 \%$ decreases of ammonia nitrogen in summer and autumn, respectively, and a higher moisture in topsoil, in addition to different above- and below-ground microclimatic conditions, with canopy cover mitigating extreme temperatures. One year after the windstorm, the microhabitat shift promoted the establishment in gaps of 15 native and 10 alien taxa previously absent in both disturbed and control plots. In such conditions, the rarefaction of the dominant $Q$. ilex canopy cover and the occurrence of empty niches prone to invasion could dramatically affect the local community structure and diversity. Our data indicate that stand-replacing windstorm can transiently transform the studied urban evergreen forest to an early allogenic successional community dominated, in the medium and large gaps, by annual and perennial non-native species. This is particularly relevant under a perspective of possible increasing frequency of windstorm events in the Mediterranean region in the near future.
\end{abstract}

Keywords: Invasive Plants, Microburst, Mediterranean Evergreen Woodland, Quercus ilex, Resources Fluctuation, Empty Niche

and energy budgets, thereby affecting native flora, fauna and ecosystem services (Hulme et al. 2009).

In forest ecosystems, plant invasion has drawn the attention of researchers, managers and policy-makers worldwide (Traveset \& Richardson 2006). The successful establishment and spread of invasive tem structure and function (Keller et al. 2011), changing hydrology, nutrient cycling

Invasive, non-native species are regarded as one of the most serious issues from both an ecological and economic perspectives (Pimentel 2011). Invaders are known to alter both terrestrial and aquatic ecosys- plants has been traditionally related to their capability to efficiently intercept and use water, light and nutrients. Accordingly, native plant communities can become susceptible to invasion when available resources are not fully used, leaving empty niches potentially exploitable by invaders (MacArthur 1970).

The fluctuating resource hypothesis states that an increase in unused resources enhances plant community susceptibility to biological invasion (Davis et al. 2000). On the other hand, invasive plants are often characterized by a more rapid growth and reproduction compared to native plants (Hierro et al. 2009), a competitive ability to modify the invaded environment (e.g., by allelochemical production - Bais et al. 2003), and a phenotypic plasticity allowing adaptation to a wide range of environmental conditions (Richards et al. 2006). Established invaders, in addition, can actively modify resource dynamics by altering the soil nutrient cycle, thus leading to plant-soil feedback fostering invader success (Ehrenfeld 2003).

The availability of unused resources, such 
as soil nutrients, may be ascribed to either a decreased uptake by native species after disturbance events (e.g., fire, windstorm, overgrazing etc.) or to an increased input by external processes (such as anthropogenic $\mathrm{N}$ deposition, increased precipitation and solar radiation) that, in turn, may accelerate nutrient release from the soil (Wang et al. 2015). Many invasive plants have been classified as "disturbance-dependent" or "early successional" species, able to colonize disturbed areas after shifts in microhabitat and resource availability (Hobbs \& Huenneke 1992). As an example, Arellano-Cataldo \& Smith-Ramírez (2016) recently reported that canopy gaps in the Robinson Crusoe Island forest showed higher density of the invasive species Aristotelia chilensis and Rubus ulmifolius compared to the understory of intact forest canopy.

Natural disturbances such as windstorms, fires, floods and landslides play an important role in the structure and function of forest ecosystems (Turner 2010). Windstorms, in particular, are considered a major disturbance process at global scale (Mitchell 2013). Their impacts to forests occur across different temporal and spatial scales (reviewed by Lugo 2008). Visible damages can range from the uprooting or breakage of a single tree to massive catastrophic losses up to thousands of hectares (Peterson 2000). The main effect on forest canopy is the formation of tree-fall gaps, which leave space for the development of new plants (Whitmore 1989). Canopy gaps, enhancing direct solar radiation to understory vegetation, can produce a community shift towards heliophytes by promoting seeds germination and growth of light-requiring species, previously suppressed by canopy shading (Vázquez-Yanes et al. 1990). Among these, many invasive plants are highly competitive in bright sunlight conditions (Poulson \& Platt 1989). On the other hand, uprooting locally produces an inversion of forest soil profile (Schaetzl 1986), which may facilitate colonization by early successional species, including invasive plants (Hobbs \& Huenneke 1992). Gap formation can alter additional resources and properties of the forest floor, such as soil moisture, temperature, and micro-topography, which can favor invasive plants development (Blair et al. 2010).

Evidence of windstorm damages to forest ecosystems is widely reported for North America (Frelich \& Lorimer 1991, Peterson 2000) and Tropics (Vandermeer \& De La Cerda 2004, Murphy et al. 2008), while reports for Europe (Jonikavičius \& Mozgeris 2013, Szmyt \& Dobrowolska 2016) and the Mediterranean region are more rare, as related to the lower occurrence and intensity of extreme events. However, windstorm frequency and impact in Mediterranean forests have been increasing since the midtwentieth century, putatively due to climate change and forest management activities (Diodato et al. 2011, Dupont et al.
2015). Such trend is expected to increase in the near future, possibly leading to a severe loss in forest structure, functioning and economic value (Seidl et al. 2014). In addition, the impact of windstorm on forest ecosystems can interact with anthropogenic activities. In the Mediterranean basin, urbanization dramatically increased in the last decades (Romano \& Zullo 2014). Urban and suburban forests are characterized by a specific ecology, being negatively affected by the surrounding urban landscape that create habitat fragmentation, induce community homogenization and so promote the spread of non-native species (McKinney 2006).

In this study, we investigated the disturbance effects of a stand-replacing windstorm generated by an extreme wet microburst in an old-growth, urban Quercus ilex forest in Southern Italy. By monitoring above- and below-ground microclimate, soil moisture and mineral nitrogen content in both disturbed and non-disturbed areas, we tested the hypothesis that altered environmental conditions promote changes in plant community composition. Specific hypothesis addressed in this study are: (i) above-ground microclimate changes in disturbed compared to non-disturbed area; (ii) windstorm disturbance drives an increase of soil resources in the forest gaps (i.e., nitrogen and soil moisture); (iii) abrupt shifts of microclimate and resources availability promote the spread of invasive plant species.

\section{Materials and methods}

\section{Study site description}

The Gussone Park of the Royal Palace of Portici (40 48' 40.3" N, $14^{\circ} 20^{\prime} 33.8^{\prime \prime}$ E, elevation $75 \mathrm{~m}$ a.s.l.; about $1 \mathrm{~km}$ distant from the coast line) hosts a 16.4 ha, even-aged old-growth evergreen holm oak Mediterranean forest, surrounded by a densely urbanized metropolitan area. Small preexisting canopy gaps and newly storm-generated gaps suggest that the dynamic of stand structure will shift from a monocohort to a more complex multi-cohort stand. The study site is located at the base of the south-western slopes of Mt. Vesuvius volcano at an elevation of $84 \mathrm{~m}$ a.s.l., facing the sea of the Gulf of Naples.

The holm oak (Quercus ilex) is the dominant tree in the forest with scattered occurrence of some deciduous species such as Fraxinus ornus, Quercus pubescens, UImus campestris, and Celtis australis. In addition, it includes some creeper plants (Hedera helix, Rubus ulmifolius, Clematis vitalba, Tamus communis) and shrubs such as Viburnum tinus. Overall, the vascular flora includes 454 species (Stinca \& Motti 2009).

A shallow soil with andic properties lays over pyroclastic deposits from eruptions of the Mount Vesuvius dated $1631 \mathrm{CE}$. The climate is Mediterranean, with humid winter and dry summer, total yearly rainfall of 929 $\mathrm{mm}$ (290, 200, 89 and $348 \mathrm{~mm}$ in winter, spring, summer, and fall, respectively), and mean monthly temperatures ranging between $11^{\circ} \mathrm{C}$ (January) and $26{ }^{\circ} \mathrm{C}$ (August).

On 16 June 2014 at $~ 13: 30$ (CEST), a wet microburst, part of a large front of severe thunderstorms hitting the Tyrrhenian coastline of Southern Italy, moved from the Gulf of Naples towards the study site. The microburst generated irregular wind patterns with local speeds exceeding 100 $\mathrm{km} \mathrm{h}^{-1}$ and hail and rain precipitations with intensity above $160 \mathrm{~mm} \mathrm{~h}^{-1}$.

\section{Forest structure and vegetation analysis}

Few days after the event, a field survey was carried out in the whole Gussone Park to assess the tree damage occurred in the forest. For all damaged trees (i.e., standing, uprooted or snapped), we measured diameter at breast height with a minimum threshold diameter of $7.5 \mathrm{~cm}$; aboveground dry biomass was estimated using ad hoc forest height curve and allometric equation for total above-ground dry biomass of Q. ilex reported in the National Inventory of Forest and Carbon of Italy (equation dw4, p. 345 - Tabacchi et al. 2011). Number and extension of canopy gaps were estimated after the windstorm in Google Earth $\mathrm{Pro}^{\oplus}$ using satellite images dated $11^{\text {th }}$ of August 2014. In a selected canopy gap of $1318 \mathrm{~m}^{2}$, one month after the windstorm, stem diameter of standing and damaged trees (i.e., uprooted and snapped) were also measured in order to compare stand attributes and aboveground dry biomass before and after the event using the above mentioned equation.

In June 2015, one year after the windstorm event, we randomly selected 5 locations where disturbance occurred. A location consisted in a disturbed area with canopy gap and a control area under closed canopy. In each location, we estimated vascular species abundance within two paired adjacent plots of $10 \times 10 \mathrm{~m}$, one in the control area and the other in the disturbed one. Then, in each selected location two paired adjacent plots, the first under closed canopy and the other within the canopy gap (hereafter referred to as "control" and "disturbed area", respectively). Plant species cover was visually assessed based on the following abundance scores: (1) rare; (2) <1\%; (3) $1-5 \%$; (4) 6-15\%; (5) 16 $-25 \%$; (6) 26-50\%; (7) 51-75\%; (8) $76-100 \%$. Plant specimens were identified according to Tutin (1980). For alien exotic species and their naturalization status, reference was made to Celesti-Grapow et al. (2009).

\section{Litter and soil nitrogen availability}

In mid-June 2015, we collected from the forest floor leaf litter using randomly positioned squared frames $(10 \times 10 \mathrm{~cm})$. A total of 20 litter samples were collected, 2 in each of the previously selected area ( 5 disturbed and 5 control). Litter samples were placed in plastic bags, transported to the laboratory, and dried at $80^{\circ} \mathrm{C}$ until reaching 
constant weight.

In the same areas, to assess the effects of disturbance on mineral nitrogen $(\mathrm{N})$ availability, a total of 40 soil samples were randomly collected, away from uprooted trees, in summer (July) and autumn (October) 2015 (10 areas $\times 2$ seasons $\times 2$ samples). All samples ( $\sim \mathrm{kg}$ each) were collected from the topsoil layer $(0-20 \mathrm{~cm})$, after removing the litter layer. Samples were packed in polyethylene bags, transferred to the laboratory within the sampling day and sieved at $2 \mathrm{~mm}$, with subsequent quantification of the coarse (diameter $>2 \mathrm{~mm}$ ) and fine (diameter $<2 \mathrm{~mm}$ ) particle fractions. Soil samples for determination of nitrate $\left(\mathrm{NO}_{3}{ }^{-}\right)$and ammonium $\left(\mathrm{NH}_{4}{ }^{+}\right)$content were prepared by mixing $1 \mathrm{~g}$ of dry pulverized soil with $1 \mathrm{ml}$ of distilled water in $2 \mathrm{ml}$ Eppendorf tube. This mixture was shaken for $20 \mathrm{~min}$ and subsequently centrifuged for $5 \mathrm{~min}$ at 13,000 rpm. The samples were analyzed with a DR 3900 Spectrophotometer (Hach, Loveland, CO, USA) by using the manufacturer kits LCK 340 for $\mathrm{NO}_{3}{ }^{-}$and LCK 303 for $\mathrm{NH}_{4}^{+}$.

\section{Above-and below-ground microclimate and soil moisture}

Microclimate and soil moisture were monitored for one year (from December $9^{\text {th }}, 2014$ to December $\left.9^{\text {th }}, 2015\right)$ using two monitoring stations in either disturbed and control areas. Each station was equipped with an Em 50 data logger, two 5TM sensors for soil moisture content and temperature and one VP3 sensor for air temperature and relative humidity (all instruments from Decagon, Pullman, WA, USA). Air temperature/humidity sensors, protected by a radiation shield, were placed $10 \mathrm{~cm}$ above the ground. The two soil moisture and temperature probes were diagonally buried into the soil at $-5 \mathrm{~cm}$ and $-20 \mathrm{~cm}$ depths, respectively. No specific direct gravimetric measurements were performed for calibrating the relation between 5TM sensor responses and actual moisture content, because the sensors were installed for comparing relative changes over time by meteorological forcing in disturbed and control areas, rather than for retrieving absolute soil moisture values. Volumetric water content data were estimated according to the standard relation proposed by the manufacturer, certifying an accuracy of $\pm 3 \%$ for soils. The data loggers were programmed to store sensor data every 30 minutes over the whole monitoring period.

Photosynthetic photon flux density (PPFD, $\lambda=400-700 \mathrm{~nm}$ ) was measured using a $\mathrm{LI}-250 \mathrm{~A}$ light meter as quantum sensor (Li-Cor Inc. Environmental, Lincoln, Nebraska, USA), located at 0, 0.5, 1.0, and 2.0 $\mathrm{m}$ above the ground of 10 locations randomly selected within disturbed and control areas. Instantaneous measurements averaged every 15 seconds were taken during bright, sunny days in July 2014.

\section{Data analysis}

Tree data from disturbed and control areas were used to estimate tree density, above-ground biomass, basal area and mean height of standing and damaged trees, the latter separately assessed for uprooted and snapped trees. Gap data from aerial imagery were used to calculate gapsize frequency distribution. Species abundance scores were transformed in percent cover data, using the mean percent value for each ordinal class, and submitted to two-way factorial ANOVA including species, area (either disturbed or control) and their interaction as fixed factors. Speciesspecific differences between disturbed and control area were assessed by means of Duncan's post-hoc test. The matrix plots $\times$ species of transformed cover data was also submitted to unconstrained ordination by Principal Component Analysis (PCA).

Litter data were tested for significant differences between disturbed and control areas fitting a Generalized Linear Mixed Model (GLMM) with gaussian error distribution and identity link function, considering area and location as fixed and random factors, respectively. Further GLMMs were fitted to test differences of soil mineral $\mathrm{N}$ content, either $\mathrm{NO}_{3}{ }^{-}$or $\mathrm{NH}_{4}{ }^{+}$, between disturbed and control areas in summer and autumn, including fixed effects of area and season, and random effect of location where soil samples were collected. In all GLMMs, pairwise differences were tested by Duncan's post-hoc test. Statistical significance was tested in all cases at $P<0.05$.

\section{Results}

Effect of windstorm on stand structure, vegetation and plant invasion

Damages produced by the windstorm on the forest canopy were highly variable in space, as related to high spatial variability of the wind pattern generated by the microburst. Windstorm was stand-replacing on 1.53 ha (i.e., $9.3 \%$ of the total forest area), which correspond to $~ 8 \%$ of the total above-ground dry biomass (estimated in $\sim 5000 \mathrm{Mg}$ in a survey before the storm event), with a total of 103 canopy gaps. Gap size ranged from $5.6 \mathrm{~m}^{2}$ up to $1632 \mathrm{~m}^{2}$, although $96.5 \%$ of the gaps had a size of less than $500 \mathrm{~m}^{2}$ (see Tab. S1 in Supplementary material). We counted 404 trees (i.e., 352 Q. ilex and 52 other broadleaved trees and conifers) uprooted or with stem breakage, mostly inside the stands (367 trees) and to a lesser extent along internal roads (37 trees).

Tab. S2 (Supplementary material) reports the number, dry biomass, basal area and quadratic mean diameter of the trees growing in the disturbed area selected for the vegetation analysis, before and after the windstorm. After the windstorm, about $65 \%$ of trees were uprooted in disturbed areas (Tab. S2). Above-ground dry biomass declined by $\sim 87 \%$. The quadratic mean diameter of the trees before the storm was $33.1 \mathrm{~cm}$, while after windstorm it became $34.3 \mathrm{~cm}$ and $30.8 \mathrm{~cm}$ for uprooted and snapped trees, respectively.

Plant species cover was significantly affected by disturbance, with effects differing for different species (Tab. S3). Unconstrained ordination by PCA showed a distinct segregation of the plots according to

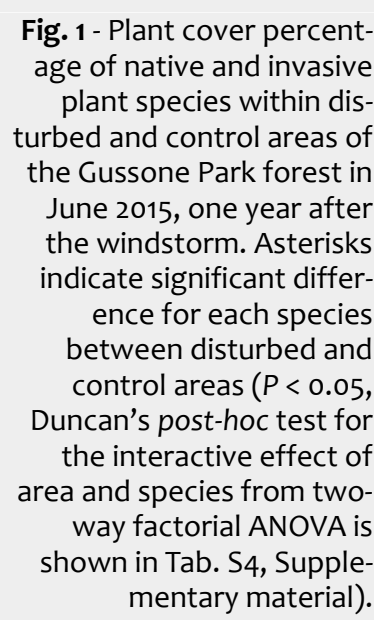

Fig. 1 - Plant cover percent ge of native and invasive plant species within disurbed and control areas of the Gussone Park forest in June 2015, one year after the windstorm. Asterisks dicate significant differ ence for each species between disturbed and control areas $(P<0.05$ uncan's post-hoc test for the interactive effect of species fromoway factorial ANOVA is mentary material).

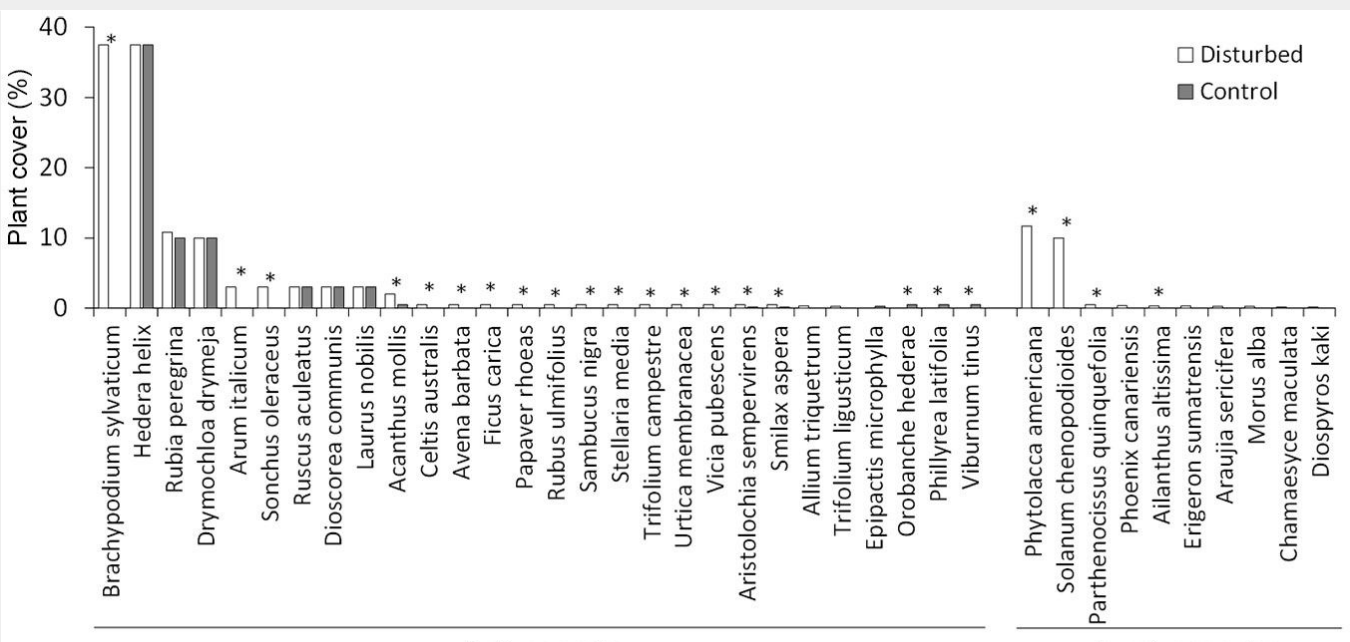

Native species 
Fig. 2 - Mineral nitrogen $\mathrm{NO}_{3}^{-}$(upper panel) and $\mathrm{NH}_{4}^{+}$

(lower panel) content in disturbed and control areas in summer (June) and autumn

(October) 2015, following the windstorm of 16 June 2014. Values are average \pm standard error of five replicates. Within each panel, different letters indicate significantly different groups (Duncan's post-hoc test for the interactive effect of disturbance occurrence and season from GLMMs is shown in Tab. S6, Supplementary material).
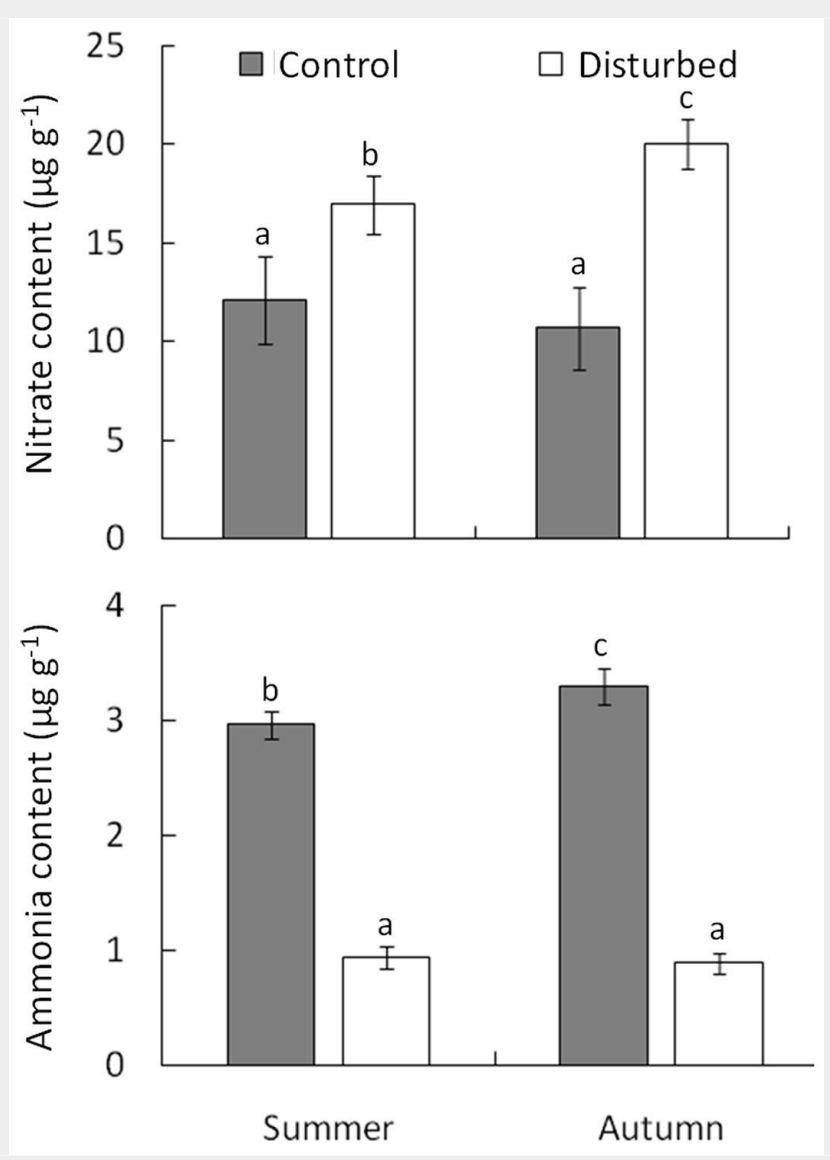

disturbance (Fig. S1 in Supplementary material), with disturbed and control plots being positively and negatively correlated to the first ordination axis, respectively, and all invasive plant species showing positive scores on the same axis. Thirty-nine plant species were recorded in the plots surveyed, with 14 life forms overall representing 32 families (Tab. S4). Among these, 10 alien invasive plant species were recorded in the disturbed area, while the control area was not subject to plant invasion. Phytolacca americana and Solanum chenopodioides were the most abundant invasive herbs (Fig. 1, Fig. S1), with other invasive species that include 3 deciduous broadleaved trees (Ailanthus altissima, Diospyros kaki and Morus alba), 1 palm (Phoenix canariensis), 2 vines (Araujia sericifera and Parthenocissus quinquefolia) and 2 annual herbs (Chamaesyce maculata and Erigeron sumatrensis). Concerning native plants, with the exclusion of Q. ilex, 15 species were exclusively recorded and 3 showed highest cover in the disturbed area, while 6 species were found in both areas with similar coverage, and 4 species were exclusively recorded in the control areas (Fig. 1, Tab. S4).

\section{Litter and mineral $\mathrm{N}$ availability}

The amount of litter was significantly

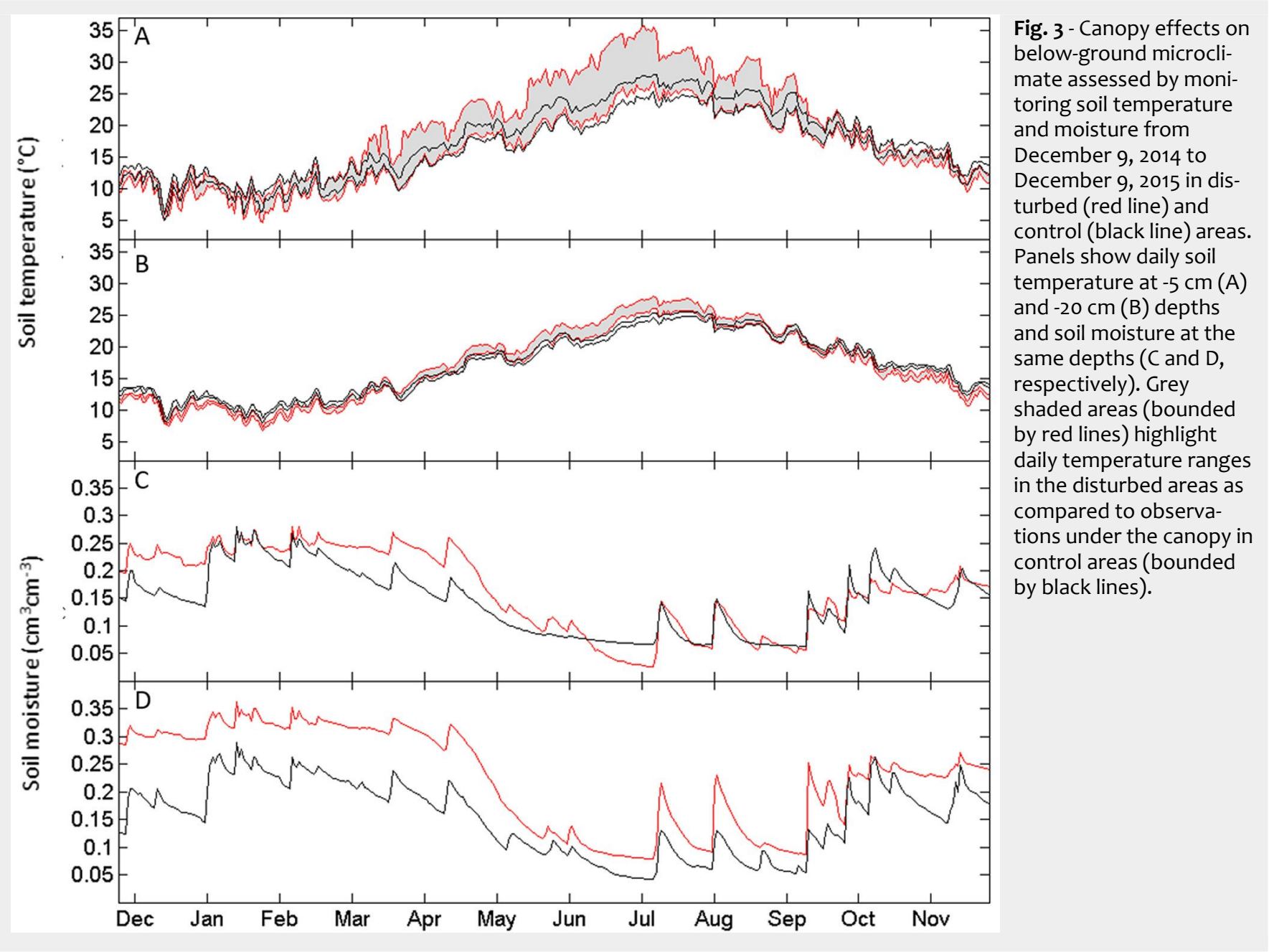


lower in disturbed areas compared to control ones $(1745.31 \pm 17.28$ and $2496.88 \pm$ $47.05 \mathrm{~g} \mathrm{~m}^{-2}$, respectively; $F_{1.20}=10.39, P=$ 0.0104 , mixed effect model - Tab. S5). On average, the content of nitrate nitrogen $\left(\mathrm{NO}_{3}-\mathrm{N}\right)$ was significantly higher in the disturbed area (Fig. 2, Tab. S6). In addition, seasonal changes in $\mathrm{NO}_{3}-\mathrm{N}$ were not consistent between disturbed and control areas (significant interaction term in Tab. S6), with differences of $28.5 \%$ and $46.6 \%$ in summer and autumn, respectively, compared to the control (Fig. 2). Differently, ammonium nitrogen $\left(\mathrm{NH}_{4}-\mathrm{N}\right)$ content in the disturbed area was lower than the control (Tab. S6), with also significant seasonal differences between disturbed and control areas (interaction term in Tab. S6) of $68.2 \%$ and $72.9 \%$ in summer and autumn, respectively (Fig. 2).

Microclimate and soil moisture content Microclimate, in terms of temperatures and moisture, exhibited a strong seasonality. Soil temperature was slightly warmer in the control area during winter months. Differently, from April to September mean daily temperature in the soil under the intact forest canopy was largely lower than that observed in the disturbed area (Fig. 3A, Fig. 3B; Fig. S2). In the disturbed areas, soil temperature at $-5 \mathrm{~cm}$ depth often reached diurnal values close to $35^{\circ} \mathrm{C}$ and remained above $30{ }^{\circ} \mathrm{C}$ for several summer weeks, while in the control area the diurnal soil surface temperature never exceeded $25^{\circ} \mathrm{C}$ (the recorded maximum was $28.4^{\circ} \mathrm{C}$ ). Air temperature in disturbed areas, compared to the control, was lower in winter but higher in spring and especially in summer (Fig. S2 in Supplementary material), with a maximum of $48.4{ }^{\circ} \mathrm{C}$, exceeding by $14.8^{\circ} \mathrm{C}$ that of the intact forest canopy.

Soil moisture exhibited a wet stage from October to May, followed by a relatively dry stage from June to September (Fig. 3C, Fig. 3D). During the wet stage, the time series showed a sequence of small pulses corresponding to rainfall events in both areas, which however resulted in higher soil moisture in the disturbed area, especially at $-20 \mathrm{~cm}$ depth (Fig. 3C, Fig. 3D).

Expectedly, PPFD within the disturbed area was significantly higher than the control, with maximum relative difference recorded at ground level, where the PPFD exceeded that of the control area by one order of magnitude (Fig. 4).

\section{Discussion}

Effects of windstorm on plant invasion

Abrupt environmental shifts produced by uprooted trees affected plant community recovery from the disturbance and recolonization within the gaps. In medium and large gaps, early colonizer species prevailed over pre-existing established herbs, lianas and tree seedlings. Noteworthy, one of the most obvious windstorm effects was the invasion of non-native species that

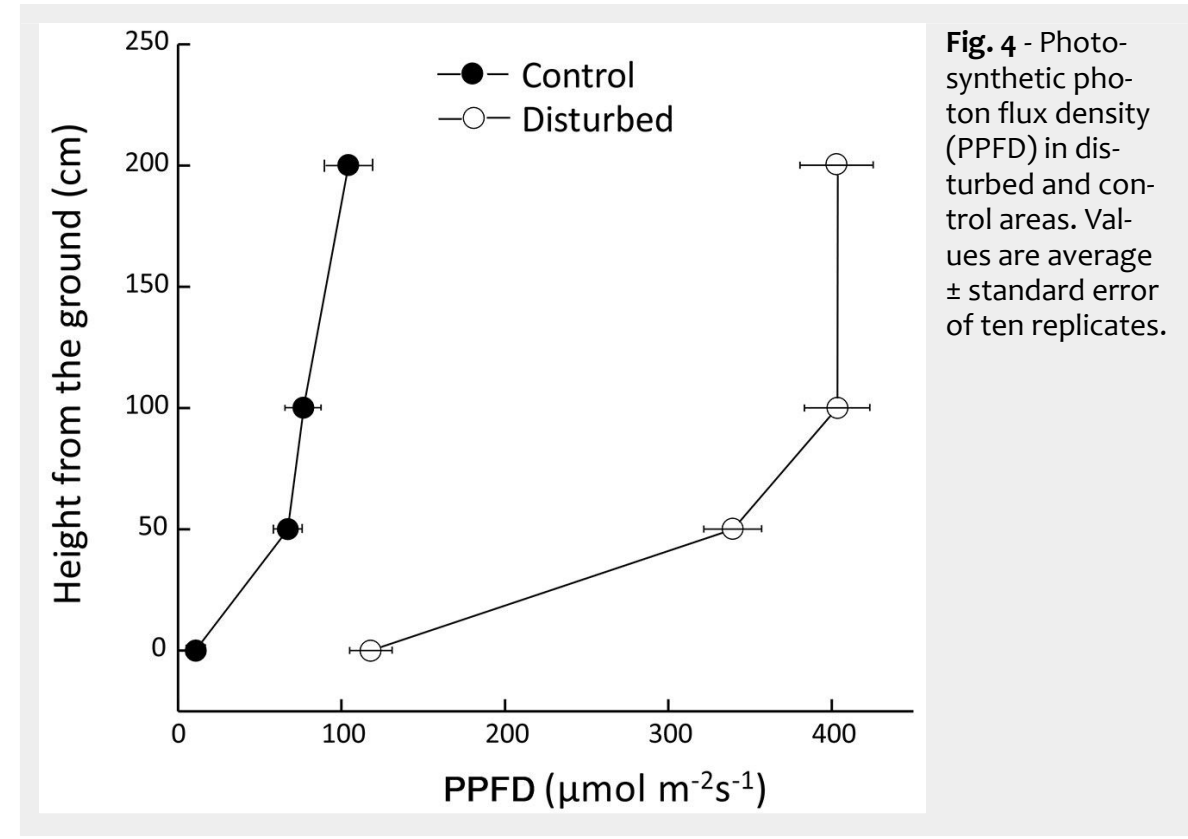

occurred only in the disturbed plots. At the community level, the windstorm acted as a disturbance removing previously established vegetation and releasing space for new pioneer species. Such alien species spreading can be explained by two complementary factors: the increase of community invasibility and the high propagule pressure at the study site. With regard to the first factor, one year after the disturbance, micro-environmental conditions within the gaps showed higher temperature with larger diurnal and seasonal fluctuations, higher light flux-density at ground level, and higher soil moisture and nitrate nitrogen content compared to undisturbed understory. As a consequence, fast-growing, early colonizer species rooted in the gaps could benefit from favorable microclimatic conditions, at least during spring and early summer seasons, as well as from improved resource availability, compared to pre-disturbance conditions. Our data are consistent with the fluctuating resource hypothesis, which states that an increase in quantity of unused resources will enhance the susceptibility of a plant community to biological invasion (Davis et al. 2000). In this regards, the absence of early recruitment of shade-tolerant species (e.g., Q. ilex) in the gaps could be due to their more limited response to the increased soil resource availability even at high light radiation levels, compared to light-demanding and/or pioneer species. An alternative hypothesis for the lack of Q. ilex seedlings, in spite of the conspicuous seed fall, could be the build-up of negative plant soil feedback due to litter autotoxicity ( $\mathrm{Li} \&$ Romane 1997, Mazzoleni et al. 2015) that may limit recruitment under conspecifics. On the other hand, our data suggest that invasive plants grow more rapidly under post-disturbance conditions compared to early colonizer native perennial species. For instance, it is surprisingly that recruitments of early colonizer, light-demanding (U. campestris, C. australis) and juvenile shade-tolerant (F. ornus) native tree species, were absent within the gaps, despite being relatively abundant in the adjacent undisturbed forest stands. Differently, seedlings of the invasive Ailanthus altissima were the most abundant in the gaps formed by the windstorm, while being absent in the control area. The impact of the light-requiring pioneer species A. altissima on Mediterranean ecosystems has been previously reported (Celesti-Grapow et al. 2009), and its invasion capability has been related to the sprouting of its sub-surficial roots, which spread rapidly in space (Lepart \& Debussche 1991). Disturbance can also favor clonal regeneration that leads to an increase of ramets from the edge of the wood or from the ramet bank, which may persist under shady condition in undisturbed stands. Our data indicate that $A$. altissima rapidly and massively colonizes post-disturbance forest gaps mainly by seed regeneration. However, further experimental work is needed to clarify the relative importance of within-gap nutrient, water, and microclifavour the colonization of this species after windstorm disturbance.

The increased community invasibility, alone, cannot explain the increased abundance and diversity of alien species recorded in forest gaps after the windstorm. The burst of several herbaceous species (e.g., P. americana and S. chenopodioides) few months after the disturbance indicates the presence of a persistent soil seed bank of non-native plants in the study site. In the case of $P$. americana, its Iongevity in the soil is well documented (Murdoch \& Ellis 2000). Moreover, the occurrence of alien species related to agricultural (e.g., Diospyros kaki and Morus alba) and gardening (e.g., Araujia sericifera and Phoenix canariensis) systems suggests that matic conditions among the factors that 
the study site is subject to a considerable propagule pressure from the adjacent open areas. In fact, the study site is an old growth forest embedded in an urban landscape, with high frequency of cultivated fields and gardens. In this context, our findings suggest that natural forests at the urban interface are particularly vulnerable to invasion by non-native plants, because suburban gardens and agricultural activity can act as significant sources of plant propagules (Alston \& Richardson 2006).

\section{Effects of windstorm on microclimatic} conditions and resource availability

The catastrophic windstorm of 16 June 2014 produced many gaps in the forest canopy caused by individual or neighborhood groups of tree falls, with gap size ranging from few square meters to more than $1600 \mathrm{~m}^{2}$. According to previous studies, gaps formed by the windstorm are characterized by greater light availability at ground level compared to closed canopy (Poulson \& Platt 1989). Besides light availability, other major environmental shifts occurred within the gaps compared to undisturbed forest areas. Among these, air and surface soil temperatures within the gaps were higher than in adjacent control areas during spring and summer, in agreement with previous studies (Gray et al. 2002, Ritter et al. 2005), but lower during winter, especially during the night. As a consequence, plants established within the gaps experienced a much wider temperature fluctuation at both daily (day vs. night) and seasonal (summer vs. winter) scale.

Among the possible environmental modifications induced by the windstorm, we showed a systematic modification of soil moisture regime within the gaps. The study area is characterized by a Mediterranean climate with alternation of cold-wet (autumn-winter) and hot-dry (spring-summer) seasons, with very short wet-to-dry and dry-to-wet transition stages. Several studies highlighted that Mediterranean summer drought establishes microclimatic conditions particularly severe for the regeneration of shrub and tree species (Allegrezza et al. 2016). In such conditions, the forest canopy buffers the local microclimatic severity by favoring a decrease of air temperature and a simultaneous increase of air relative humidity during the hottest hours of the summer days, thus contributing to mitigate vapor pressure deficit, leaf temperature and transpiration losses. Canopy light interception also reduces the amount and modifies the quality of incident solar radiation transmitted to the ground, reducing soil heating and soil evaporation losses. In spite of higher soil temperature and lower air relative humidity, soil moisture was higher within the gaps during winter and spring. A higher soil water content in forest gaps has been previously reported (Gray et al. 2002, Ritter et al. 2005), but not in the Mediterranean region. Higher soil moisture in the gap is probably due to lower canopy interception, which can reach $\sim 13 \%$ of total rainfall in olm oak forests (Bellot et al. 1999), and lower transpiration losses. Some previous studies (Denslow et al. 1998) reported a reduction in fine root biomass following treefall, suggesting the hypothesis of reduced transpiration losses in gaps soils. Our data are consistent with such hypothesis, because soil water content differences between intact canopy and gaps are highest in winter and spring but not in the driest summer days, when soil water reached the minimum content values.

The soil in gaps, in addition to higher moisture content, had higher nitrate nitrogen content compared to undisturbed areas. Our results are apparently contrasting with previous findings by Zimmerman et al. (1995), reporting that, after a hurricane in tropical forest, decomposition of fresh leaf litter and wood debris from tree falls induced long-term $\mathrm{N}$ immobilization, with depressive effects on net primary productivity in the first 13 years following the disturbance. In addition, our previous studies carried out in the study site showed that decomposition of Q. ilex leaf litter determines a net $\mathrm{N}$ immobilization lasting for several months (Bonanomi et al. 2014), as related to its relatively high $\mathrm{C} / \mathrm{N}$ ratio. This apparent contradiction could be explained by a fast mineralization of soil organic matter within the gaps that may overbalance the $\mathrm{N}$ immobilization by degradation of $\mathrm{Q}$. ilex leaves and especially wood debris with high $\mathrm{C} / \mathrm{N}$ ratio $(>100)$. Indeed, $\mathrm{N}$ transfer and immobilization by microbes becomes ecologically relevant during the early phases of litter decomposition, when $\mathrm{C} / \mathrm{N}$ ratio of the decomposing substrate is above a critical threshold of $\sim 30-35$, which leads to microbial $\mathrm{N}$ starvation. In this context, our hypothesis is that the accumulation of nitrate nitrogen could be related to higher soil temperature and water content enhancing organic matter mineralization rates during spring and early summer. On the other hands, we expect that $\mathrm{N}$ immobilization will become quantitatively more relevant in the long term (i.e., some years after the windstorm), as a consequence of the progressive degradation of wood debris and the litter migration to ground level. Quantification of accumulated wood debris and of the subsequent decomposition process is important to understand the impact of necromass on soil processes as well as on food-web structure and functionality. Our on-going studies are addressing the impact of dead wood and leaf litter on microbiome structure and diversity by using high-throughput sequencing of bacterial and eukaryotic rRNA gene markers.

\section{Conclusions}

We showed that extreme windstorm events affect forest structure driving to sudden environmental shifts, such as modifications of micro-climatic conditions and soil resources. At the community level, windstorms can foster the spread of several invasive species, likely by removing the dominant evergreen tree Q. ilex, thus providing empty niches for many short-lived herbs, as well as some early colonizer and non-native trees. The spread of alien plants could eventually drive to alternative successional trajectories that may dramatically affect community structure and diversity. These data are the first to show a multiple plant invasion after a windstorm disturbance in the Mediterranean region that can potentially transform an urban evergreen forest to an early successional community dominated by non-native deciduous species. This finding is relevant to appreciate the potential ecological implications of infrequent disturbance in Mediterranean forest ecosystems in the context of climatic change. Under global warming, the frequency and intensity of windstorm is expected to increase (Seidl et al. 2014), potentially enhancing plant community invasion by non-native plants. Future studies are urgently required to assess the interactive effects of extreme weather events, community invasibility, and propagule pressure in order to understand their relative importance for the spreading of invasive plants, and evaluate their ecological and economic impacts.

\section{References}

Allegrezza M, Corti G, Cocco S, Pesaresi S, Chirico GB, Saracino A, Bonanomi G (2016). Microclimate buffering and fertility island formation during Juniperus communis ontogenesis modulate competition-facilitation balance. Journal of Vegetation Science 27: 616-627. - doi: 10.1111/jvs.12386

Alston KP, Richardson DM (2006). The roles of habitat features, disturbance, and distance from putative source populations in structuring alien plant invasions at the urban/wildland interface on the Cape Peninsula, South Africa. Biological Conservation 132: 183-198. - doi: 10.1016/j.biocon.2006.03.023

Arellano-Cataldo G, Smith-Ramírez C (2016). Establishment of invasive plant species in canopy gaps on Robinson Crusoe Island. Plant Ecology 217: 289-302. - doi: 10.1007/s11258-016-0570-4

Bais HP, Vepachedu R, Gilroy S, Callaway RM, Vivanco JM (2003). Allelopathy and exotic plant invasion: from molecules and genes to species interactions. Science 301: 1377-1380. - doi: 10.1126/science.1083245

Bellot J, Avila A, Rodrigo A (1999). Throughfall and stemflow. In: "Ecology of Mediterranean evergreen oak forests" (Rodà F, Retana J, Gracia CA, Bellot J eds). Springer, Berlin Heidelberg, Germany, pp. 209-222. - doi: 10.1007/9783-642-58618-7_15

Blair BC, Letourneau DK, Bothwell SG, Hayes GF (2010). Disturbance, resources, and exotic plant invasion: gap size effects in a redwood forest. Madroño 57: 11-19. - doi: 10.3120/0024-9637-57.1. 11

Bonanomi G, Capodilupo M, Incerti G, Mazzoleni $S$ (2014). Nitrogen transfer in litter mixture enhances decomposition rate, temperature sensitivity, and C quality changes. Plant and Soil 381: 
307-321. - doi: 10.1007/s11104-014-2119-4

Celesti-Grapow L, Alessandrini A, Arrigoni PV, Banfi E, Bernardo L, Bovio M, Brundu G, Cagiotti MR, Camarda I, Carli E, Conti F, Fascetti S, Galasso G, Gubellini L, La Valva V, Lucchese F, Marchiori S, Mazzola P, Peccenini S, Poldini L, Pretto F, Prosser F, Siniscalco C, Villani MC, Viegi L, Wilhalm T, Blasi C (2009). Inventory of the non-native flora of Italy. Plant Biosystems 143: 386-430. - doi: 10.1080/11263500902722824 Davis MA, Grime JP, Thompson K (2000). Fluctuating resources in plant communities: a general theory of invasibility. Journal of Ecology 88: 528-534. - doi: 10.1046/j.1365-2745.2000.00473.x Denslow JS, Ellison AM, Sanford RE (1998). Treefall gap size effects on above- and belowground processes in a tropical wet forest. Journal of Ecology 86: 597-609. - doi: 10.1046/j.13652745.1998.00295.x

Diodato N, Bellocchi G, Romano N, Chirico GB (2011). How the aggressiveness of rainfalls in the Mediterranean lands is enhanced by climate change. Climatic Change 108: 591-599. doi: 10.1007/s10584-011-0216-4

Dupont S, Pivato D, Brunet Y (2015). Wind damage propagation in forests. Agricultural and Forest Meteorology 214: 243-251. - doi: 10.1016/j. agrformet.2015.07.010

Ehrenfeld JG (2003). Effects of exotic plant invasions on soil nutrient cycling processes. Ecosystems 6: 503-523. - doi: 10.1007/s10021-002-0151-3 Frelich LE, Lorimer CG (1991). Natural disturbance regimes in hemlock-hardwood forests of the upper Great Lakes region. Ecological Monograph 61: 145-164. - doi: 10.2307/1943005

Gray AN, Spies TA, Easter MJ (2002). Microclimatic and soil moisture responses to gap formation in coastal Douglas-fir forests. Canadian Journal of Forest Research 32: 332-343. - doi: 10.1139/x01-200

Hierro JL, Eren O, Khetsuriani L, Diaconu A, Török K, Montesinos D, Andonian K, Kikodze D, Janoian L, Villarreal D (2009). Germination responses of an invasive species in native and non-native ranges. Oikos 118: 529-538. - doi: 10.1111/j.1600-0706.2008.17283.x

Hobbs RJ, Huenneke LF (1992). Disturbance, diversity, and invasion: implications for conservation. Conservation Biology 6: 324-337. - doi: 10.1046/j.1523-1739.1992.06030324.x

Hulme PE, Pyšek P, Nentwig W, Vilà M (2009). Will threat of biological invasions unite the European Union. Science 324: 40-41. - doi: 10.1126/ science.1171111

Jonikavičius D, Mozgeris G (2013). Rapid assessment of wind storm-caused forest damage using satellite images and stand-wise forest inventory data. iForest 6: 150-155. - doi: 10.3832/ ifor0715-006

Keller RP, Geist J, Jeschke JM, Kühn I (2011). Invasive species in Europe: ecology, status, and policy. Environmental Sciences Europe 23: 1-17. doi: 10.1186/2190-4715-23-23

Lepart J, Debussche M (1991). Invasion processes as related to succession and disturbance. In: "Biogeography of Mediterranean Invasions" (Groves RH, Di Castri F eds). Cambridge University Press, Cambridge, UK, pp. 159-178. - doi: 10.1017/CBO9780511525544

Li J, Romane FJ (1997). Effects of germination inhibition on the dynamics of Quercus ilex stands. Journal of Vegetation Science 8: $287-$ 294. - doi: $10.2307 / 3237358$

Lugo AE (2008). Visible and invisible effects of hurricanes on forest ecosystems: an international review. Austral Ecology 33: 368-398. doi: 10.1111/j.1442-9993.2008.01894.x

MacArthur RH (1970). Species packing and competitive equilibrium for many species. Theoretical Population Biology 1: 1-11. - doi: 10.1016/004 0-5809(70)90039-0

Mazzoleni S, Bonanomi G, Incerti G, Chiusano ML, Termolino P, Mingo A, Lanzotti V (2015). Inhibitory and toxic effects of extracellular selfDNA in litter: a mechanism for negative plantsoil feedbacks? New Phytologist 205: 1195-1210. doi: 10.1111/nph.13121

McKinney ML (2006). Urbanization as a major cause of biotic homogenization. Biological Conservation 127: 247-260. - doi: 10.1016/j.biocon.20 05.09 .005

Mitchell S (2013). Wind as a natural disturbance agent in forests: a synthesis. Forestry 2: 147-157. doi: 10.1093/forestry/cps058

Murdoch AJ, Ellis RH (2000). Dormancy, viability and longevity. In: "Seeds: the ecology of regeneration in plant communities ( $2^{\text {nd }}$ edn)" (Fenner $M$ ed). CABI Publishing, Wallingford, UK, pp. 183-214. - doi: 10.1079/9780851994321.0000 Murphy HT, Metcalfe DJ, Bradford MG, Ford A, Galway K, Sydes T, Westcott D (2008). Recruitment dynamics of invasive species in rainforest habitats following Cyclone Larry. Austral Ecology 33: 495-502. - doi: 10.1111/j.1442-9993.2008. 01904.x

Peterson CJ (2000). Catastrophic wind damage to North American forests and the potential impact of climate change. Science of the Total Environment 262: 287-311. - doi: 10.1016/Soo489697(00)00529-5

Pimentel D (2011). Biological invasions: economic and environmental costs of alien plant, animal, and microbe species. CRC Press, Boca Raton, USA, pp. 463. [online] URL: http://books.goo gle.com/books?id=wDbNBQAAQBAJ

Poulson TL, Platt WJ (1989). Gap light regimes influence canopy tree diversity. Ecology 70: 553-555. - doi: 10.2307/1940202

Richards CL, Bossdorf O, Muth NZ, Gurevitch J, Pigliucci M (2006). Jack of all trades, master of some? On the role of phenotypic plasticity in plant invasions. Ecology Letters 9: 981-993. doi: 10.1111/j.1461-0248.2006.00950.x

Ritter E, Dalsgaard L, Einhorn KS (2005). Light, temperature and soil moisture regimes following gap formation in a semi-natural beech-dominated forest in Denmark. Forest Ecology and Management 206: 15-33. - doi: 10.1016/j.foreco. 2004.08.011

Romano B, Zullo F (2014). Land urbanization in Central Italy: 50 years of evolution. Journal of Land Use Science 9: 143-164. - doi: 10.1080/1747 $423 X .2012 .754963$

Schaetzl RJ (1986). Complete soil profile inversion by tree uprooting. Physical Geography 7: 181-189. [online] URL: http://www.tandfonline. com/doi/abs/10.1080/02723646.1986.10642290 Seidl R, Schelhaas M-J, Rammer W, Verkerk PJ (2014). Increasing forest disturbances in Europe and their impact on carbon storage. Nature Climate Change 4: 806-810. - doi: 10.1038/nclimate2318
Stinca A, Motti R (2009). The vascular flora of the Royal Park of Portici (Naples, Italy). Webbia 64: 235-266. - doi: 10.1080/00837792.2009.106 70861

Szmyt J, Dobrowolska D (2016). Spatial diversity of forest regeneration after catastrophic wind in northeastern Poland. iForest 9: 414-421. - doi: 10.3832/ifor1699-008

Tabacchi G, Di Cosmo L, Gasparini P, Morelli S (2011). Stima del volume e della fitomassa delle principali specie forestali italiane. Equazioni di previsione, tavole del volume e tavole della fitomassa arborea epigea [Volume and phytomass estimation of the main Italian forest species. Forecast equations, tables of volume and of above ground phytomass]. Consiglio per la Ricerca e la sperimentazione in Agricoltura, Unità di Ricerca per il Monitoraggio e la Pianificazione Forestale, Trento, Italy, pp. 343-356. [in Italian]

Traveset A, Richardson DM (2006). Biological invasions as disruptors of plant reproductive mutualisms. Trends in Ecology and Evolution 21: 208-216. - doi: 10.1016/j.tree.2006.01.006

Turner MG (2010). Disturbance and landscape dynamics in a changing world. Ecology 91: 28332849. - doi: 10.1890/10-0097.1

Tutin TG (1980). Flora Europaea, vol 1-5. Cambridge University Press, Cambridge, UK, pp. 476. [online] URL: http://books.google.com/ books?id=v11xJgWbUDcC

Vandermeer J, De La Cerda IG (2004). Height dynamics of the thinning canopy of a tropical rain forest: 14 years of succession in a post-hurricane forest in Nicaragua. Forest Ecology and Management 199: 125-135. - doi: 10.1016/j.fore c0.2004.05.033

Vázquez-Yanes C, Orozco-Segovia A, Rincon EEA, Sanchez-Coronado ME, Huante P, Toledo JR, Barradas VL (1990). Light beneath the litter in a tropical forest: effect on seed germination. Ecology 71: 1952-1958. - doi: 10.2307/1937603

Wang C, Xiao H, Liu J, Wang L, Du D (2015). Insights into ecological effects of invasive plants on soil nitrogen cycles. American Journal of Plant Sciences 6: 34-46. - doi: 10.4236/ajps. 2015.61005

Whitmore TC (1989). Canopy gaps and two major groups of forest trees. Ecology 70: 536538. - doi: 10.2307/1940195

Zimmerman JK, Pulliam WM, Lodge DJ, Quiñones-Orfila V, Fetcher N, Guzman-Grajales S, Parrotta JA, Asbury CE, Walker LR, Waide RB (1995). Nitrogen immobilization by decomposing woody debris and the recovery of tropical wet forest from hurricane damage. Oikos 72: 314-322. - doi: $10.2307 / 3546116$

\section{Supplementary Material}

Fig. S1 - PCA biplot of species and plots.

Fig. S2 - Canopy effects on above-ground microclimate assessed by monitoring air temperature and relative humidity from December 92014 to December 92015 in disturbed and control areas.

Tab. S1 - Gap-size distribution in the study forest following the windstorm of 16 June 2014. 
Tab. S2 - Forest stand attributes before and after (June 2015) the windstorm.

Tab. S3 - Results of two-way factorial Tab. S5 - Results of the GLMM testing for ANOVA (F statistics and associated P-value) effects of the sampling area and location testing for effects of the sampling area, and their interaction on the amount of lit-

plant species and their interaction on plant ter collected at the sampling site.
Tab. S4 - List of plant species recorded in the disturbed and control areas.
Tab. S6 - Results of the GLMM testing for the effects of sampling area, location and collection season on $\mathrm{NO}_{3}$ and $\mathrm{NH}_{4}{ }^{+}$content in soil samples collected at the sampling site.

Link: Bonanomi_2374@@supplo01.pdf cover. 